\title{
TTR
}

Traduction, terminologie, re?daction

\section{Traducción y di-ferencia, edited by Assumpta Camps, Montserrat Gallart, Iván García and Victoriano Peña, Barcelona, Universitat de Barcelona, 2006.}

\section{María Sierra Córdoba Serrano}

Volume 18, numéro 1, 1er semestre 2005

Traductions et représentations : Parcours dans l'espace hispanique II

Translations and Representations: Exploring the Hispanic World II

URI : https://id.erudit.org/iderudit/014377ar

DOI : https://doi.org/10.7202/014377ar

Aller au sommaire du numéro

Éditeur(s)

Association canadienne de traductologie

ISSN

0835-8443 (imprimé)

1708-2188 (numérique)

Découvrir la revue

Citer ce compte rendu

Serrano, M. S. C. (2005). Compte rendu de [Traducción y di-ferencia, edited by Assumpta Camps, Montserrat Gallart, Iván García and Victoriano Peña, Barcelona, Universitat de Barcelona, 2006.] TTR, 18(1), 258-264.

https://doi.org/10.7202/014377ar d'utilisation que vous pouvez consulter en ligne. 
également toujours attendre. Cependant, ces desiderata n'empêchent pas ce numéro thématique d'être un pas décisif vers une véritable sociologie de la traduction. Il reste à souhaiter que cette étude-clé trouve, au sein de la communauté scientifique des traductologues, l'écho qu'elle réserverait à un ouvrage de cette qualité rédigé en anglais. La socio-traductologie est elle aussi un sport de combat.

\section{Alexandra Fukari Université de Graz, Autriche}

\section{Traducción y di-ferencia, edited by Assumpta Camps, Montserrat Gallart, Iván García and Victoriano Peña, Barcelona, Universitat de Barcelona, 2006.}

The present volume is the result of the work carried out by the CRETGrup de Recerca Consolitat de la Universitat de Barcelona and it is the third volume of Transversal, a collection specialized in contemporary thought on translation. Composed of 21 articles, very different in approach and theme, Traducción y di-ferencia offers an interesting overview of the impact post-structuralism has had on Translation Studies.

Drawing primarily on Derrida, Barthes and Foucault, translation theorists have recognized that meanings are inherently non-stable and must be interpreted in every instance: each reading of a text (and, consequently, each translation) produces a simulacrum of an "original" that is itself the mark of the shifting and unstable subject, using and being used by a language that is also shifting and unstable (Derrida, 1998). Under this assumption, the dichotomy between original and translation no longer applies as the original is not conceived as a depositary of an intentio operis (Umberto Eco) nor the translation a replica of this authorial intention. As Camps indicates in the prologue (p. 30) it is precisely the post-structural revision of dichotomies such as original vs. translation, author vs. translator, fidelity vs. betrayal and the authors' reflections on the phenomenon of "translation as difference" that constitutes the common denominator at the core of this otherwise diverse volume.

Although the articles in this volume are not divided into subcategories, but merely organized by alphabetical order, I will group them here by "theme" in order to facilitate the presentation of the 
content. I am aware, however, that some articles may seem to have been forced into groups or that the grouping may be oversimplified. As we will see later, this is somewhat the result of the organizational shortcoming of the present volume.

Comellas ${ }^{2}$ presents Kundera's and Borges's radically opposite positions on authorial meaning: whereas for Kundera "La obra es la casa del autor y de nadie más, y las reescrituras son una especie de mal necesario, intermediarias indeseables pero imprescindibles" [The work is the author's house and nobody else's, and rewritings are a necessary evil, undesirable intermidiaries, but very much needed] (p. 98), for Borges "Presuponer que toda recombinación de elementos es obligatoriamente inferior a su original es presuponer que el borrador 9 es obligatoriamente inferior al borrador $\mathrm{H}$ - ya que no puede haber sino borradores. El concepto de texto definitivo no corresponde sino a la religión o al cansancio" [To assume that every combination of elements is inferior to its original involves saying that draft number 9 is necessarily inferior to draft $\mathrm{H}$, as there can only be drafts. The concept of definitive text does not emanate but from religion or tiredness] (p. 105).

Borges is also the protagonist of Camps essay ${ }^{3}$. She highlights the originality and innovation of Borges's thought on translation for his time. In fact, already in the 1930s Borges had offered some ideas that only years later would find echo in post-structuralist criticism.

Several articles focus on the concepts of "fidelity" vs. "betrayal" or "success" vs. "failure" of a translation: Bosak ${ }^{4}$ synthesizes the formulations of authors as diverse as Nietzsche, Eco, Borges, Haroldo de Campos, and Larbaud, while the Lessa article ${ }^{5}$ expands on Haroldo de Campos and his anthropophagic school's approach, who conceive

\footnotetext{
2 “Autoría contra traducción y traducción como autoría: las perspectivas de Kundera y Borges,” pp. 95-110.

3 “La vida del texto: Borges y la traducción,” pp. 63-74.

4 “Entre el fracaso y la traición: una mirada imperfecta hacia la traducción,” pp. 37-44.

5 "Estudios de traducción y literatura comparada. El caso de Haroldo de Campos (1923-2003),” pp. 179-188.
} 
translation as "una re-creación, o creación paralela, autónoma y todavía recíproca” [a re-creation or parallel creation, autonomous and yet reciprocal] (p. 181). Godayol ${ }^{6}$, for her part, focuses her reflection on reading translation practices from an intertextual angle in which the translator tries to reproduce a previous moment of intertextuality, participating, simultaneously, in a new network of intertexts specific to a new community.

Another aspect discussed in detail is the phenomenon of selftranslation. Within this theme, the articles by Crolla ${ }^{7}$ and Zaboklicka ${ }^{8}$ both examine the case of the Polish writer Gombrowicz, who lived in exile in Argentina for 24 years after the outbreak of the Second World War. Together with a group of young South-American writers, he translated his own work, his "Spanish Ferdydurke", which was considered by the critics "as a highly creative version" rather than as "an academic translation" (Zaboklicka, p. 340). The fact that he translated his own work makes the discussions concerning the translator's margin of manœuvre (Zaboklicka, p. 340) irrelevant, as translation becomes a new process of creation for the author. Recio ${ }^{9}$, in turn, examines the self-translations carried out by the Catalan writer Carmen Riera, and the subsequent decision by Luisa Cotoner to retranslate Riera's self-translation. According to Cotoner, Riera's version contains unjustified omissions and losses, which Recio explains can be attributed to market reasons, "oportunismo editorial” (p. 282), as she puts it.

This volume also contemplates recognized writers that translate others. This is the case in the Gallart ${ }^{10}$ and García ${ }^{11}$ articles. Whereas

\footnotetext{
6 “Traducir desde la intertextualidad: lecturas y contaminaciones,” pp. 161-170.

7 "Leer es traducir - traducir es trans-decir un paradigma de lectura," pp. 111126.
}

8 "El casamiento/El matrimonio de Witold Gombrowicz: versión versus traducción,” pp. 337-352.

9 “Autotraducción, traducción y moda literaria: los primeros cuentos de Carmen Riera,” pp. 265-286.

10 "Sobre L'art de traduire yourcenariano y su práctica traductológica," pp. 127-144. 
the former focuses on the interventionist translation work done by Yourcenar, the latter analyses Tolstói's translation of the Evangel (a work undertaken primarily as a way to demonstrate his own philosophy concerning the meaning of life).

From these rather hermeneutic perspectives, we move to more external and sociological ones. Luna ${ }^{12}$, using the polysystem theory as her theoretical framework, analyses the Galician literary system, in particular the inter-systemic relationships between the Spanish and the Galician literary systems in the last twenty years. Romano ${ }^{13}$, for her part, focuses on the current panorama of literary translation in Italy, especially the translator and his/her social status.

Other articles of this volume discuss cases involving the French literary field. Piquer ${ }^{14}$ analyses the translation in Spain of French authors from the $16^{\text {th }}$ and $17^{\text {th }}$ centuries, examining with more attention the case of the author most translated, Molière and, at the other side of the spectrum, the relatively untranslated authors (given their reputation) such as Corneille, Racine, and other poets from the French Renaissance and the Baroque period. Mallart ${ }^{15}$ analyses the problematic translation of the French pronoun on in André Breton and Philippe Soupault's surrealist manifesto, Los campos magnéticos. The translation of on is paramount because it symbolizes the undefinition and ambiguity that epitomize the new surrealist subject, yet in Spanish translation personal pronouns must always define the person they refer to, hence the problem.

11 “Tolstói traduce el Evangelio,” pp. 145-160.

12 "Sobre las relaciones entre el sistema literario gallego y el castellano en la época contemporánea a través de la traducción,” pp. 189-208.

13 "Las voces femeninas de la traducción literaria italiana: panorámica y problemática de la profesión,” pp. 287-310.

14 "La traducción de clásicos franceses en las postrimerías del siglo XX," pp. 249-264.

15 “La traducción de Los campos magnéticos: el caso del pronombre On,” pp. 209-220. 
Still in the European space, but now changing to Italy, Peña ${ }^{16}$ examines the theoretical writings on literary-and more precisely poetic-translation by the poet and translator Franco Fortini.

Moving now to the South American cultural space, Gomes ${ }^{17}$ reflects on alterity in the translation of frontier literature, focusing in particular on Benjamín de Garay's translation of Os Sertões by Euclides da Cunha, while the Canós article ${ }^{18}$ studies the translation into Spanish of Chicana literature written in English. In particular, Canós analyses the two Spanish translations (one in peninsular Spanish and the other in Mexican Spanish) of Sandra Cisneros The House on Mango Street and the implications of choosing one dialectic variety of Spanish over the other in terms of critical reception. In the same vein, the Serrano article ${ }^{19}$ comments on the tendency of Mexican publishing houses to publish exactly the same translations that are published in Spain due to commercial reasons, the subsequent result being, according to him, a "foreign" text.

With a focus on non-Eurocentric paradigms of translation, the remarkable Sales article ${ }^{20}$ examines the thought of professor P. Lal, poet, critic, translation theorist, and translator of Indian literature into English. According to Sales, the goal of her contribution is "aportar una modesta contribución que ayude a paliar las lagunas bibliográficas que tenemos acerca de cómo se piensa sobre la traducción más allá del pensamiento occidental” [To provide a modest contribution that helps cover existing bibliographical gaps concerning how to think about translation beyond Western paradigms] (p. 311).

\footnotetext{
16 "Literatura, traducción y sociedad. Sobre la reflexión traductora de Franco Fortini,” pp. 237-248.

17 “Os Sertões: ¿una obra intraducible? - Benjamín de Garay, traductor de Euclides da Cunha,” pp. 171-178.

18 “Tensiones dialectales en la traducción hispánica: un ejemplo de la literatura chicana,” pp. 75-94.

19 “Para una propuesta de traducción del español de México,” pp. 323-336.

20 "Pensamiento sobre la traducción en la India: la aportación de P. Pal," pp. 311-322.
} 
Finally, in a different context and conceiving translation in a broader sense-not only as an inter-lingual activity, but also an intersemiotic one-Moya ${ }^{21}$ analyses the cinematographic adaptations of literary works. In particular, she looks at The Remains of the Day (Ishiguro), and its cinematographic version, which, according to her, suppresses the polyphony of voices of the novel. Distanced in time and in theme from the other articles, Butinyà's work ${ }^{22}$ analyses medieval translations, which, according to her, constitute a form of adaptationmore precisely, a vulgarization-rather than a translation in the strictest sense of the concept. In particular, she studies the medieval translation of Ovidi enamorat by Metge, a translation work that is considered by Butinyà as a turning point in the translation practices of the $14^{\text {th }}$ century, and as an advancement towards modern conceptions of translation practices.

This volume presents several merits: first, the diversity with which it approaches the phenomenon of translation (from more external and sociological approaches to more internal-hermeneutic ones; from the point of view of texts to the point of view of subjects); secondly, it covers different geographical spaces and different paradigms, including the non-Eurocentric ones (a subject often neglected in the field of Translation Studies).

As well, the different articles offer not only what translation theorists or translators themselves have thought and written on translation, but also notes recognized "agents" outside the field, such as philosophers, semioticians or writers, whose thought has differed from traditional conceptions of translation and has served to highlight the discipline's centrality to contemporary thought on language, culture and identity, as opposed to its conception as a purely linguistic process. In this sense, we can say that Traducción y di-ferencia completely abandons traditional comparative analyses of original and target text which emit evaluative judgments about translations, and conceives translation as a general form of rewriting that, as such, can involve a loss, but that can also improve the original, which is also in many ways "a mere draft" (Borges). Although this revision of key concepts is not

21 “J. Ivory frente a K. Ishiguro: Narrativa, identidad y política en The Remains of the Day (Lo que queda del día),” pp. 221-236.

22 "Los pasos hacia la modernidad desde la traducción a partir de la Edad Media, pasando por el Ovidi enamorat,” pp. 45-62. 
new in Translation Studies, the present volume constitutes an important contribution to the Hispanic field of Translation Studies, where comparative and evaluative analyses are still presented.

In spite of the multiciplicity of approaches and points of view presented in this volume, it is unfortunate that the concept of literary translation remains reduced to fiction. As in most publications in Translation Studies, works of knowledge are not studied or mentioned here. Perhaps another shortcoming of this volume is that certain articles do not exactly fit within the general theme. It would have been more appropriate to expand on some excellent articles that this book contains, instead of artificially introducing so many. Lastly, the number of typos detracts somewhat from the otherwise professional nature of the work.

\section{References}

DERRIDA, Jacques (1998). Of Grammatology. Translation by Gayatri Chakravorty Spivak, corrected edition. London, The Johns Hopkins University Press.

\section{María Sierra Córdoba Serrano University of Ottawa}

Berman Antoine, La prueba de lo ajeno; Cultura y traducción en la Alemanía Romántica, Traducción de Rosario García López, ed. ULPGC, Universidad de las Palmas de Gran Canaria, 2003.

On ne peut que saluer la traduction en espagnol de l'ouvrage d'Antoine Berman, L'épreuve de l'étranger, traduit en anglais il y a déjà plus de dix ans. ${ }^{23} \mathrm{~S}$ 'il est cité à maintes reprises par un certain nombre de chercheurs dans le monde, c'est au Canada qu'on lui aura fait la place qu’il mérite. $^{24}$

\footnotetext{
${ }^{23}$ Berman Antoine, The Experience of the Foreign: Culture and Translation in Romantic Germany, translated by S. Heywaert, Albany, N.Y, State University of New York, 1992, 250p.

${ }^{24}$ Antoine Berman aujourd'hui, sous la direction d'Alexis Nouss, TTR, 14, 2, 2001.
} 